\title{
Scientific Method and Juridical Accountability in Mario Calderoni's Pragmatism
}

Rosa M. Calcaterra

\section{(2) OpenEdition}

Journals

Electronic version

URL: http://journals.openedition.org/ejpap/1539

DOI: 10.4000/ejpap.1539

ISSN: 2036-4091

\section{Publisher}

Associazione Pragma

\section{Electronic reference}

Rosa M. Calcaterra, "Scientific Method and Juridical Accountability in Mario Calderoni's

Pragmatism », European Journal of Pragmatism and American Philosophy [Online], XI-1 | 2019, Online since 19 July 2019, connection on 21 July 2019. URL : http://journals.openedition.org/ejpap/1539 ; DOI : 10.4000/ejpap.1539

This text was automatically generated on 21 July 2019.

\section{c) (i) $(-)$}

Author retains copyright and grants the European Journal of Pragmatism and American Philosophy right of first publication with the work simultaneously licensed under a Creative Commons AttributionNonCommercial-NoDerivatives 4.0 International License. 


\title{
Scientific Method and Juridical Accountability in Mario Calderoni's Pragmatism
}

\author{
Rosa M. Calcaterra
}

1 Calderoni's pragmatism is characterized by a polemical stance towards some important William James's theses. This controversy was one with his philosophical choice in favor of Peirce's pragmatism. We could define this choice as ethically founded, that is, as linked to the typically Peircean attribution of a strong ethical value to the scientific-experimental method.

2 The ethical choice in favor of Peirce's pragmatism seems to be confirmed as long as Calderoni identifies a third form of pragmatism, in addition to the Peircean and Jamesian versions. In the two writings published at a short distance on "Leonardo" - i.e Le varietà del pragmatismo (November 1904) and Variazioni sul pragmatismo (February 1905) Calderoni defines three forms of pragmatism: 1) the "critical" pragmatism, which, in harmony with Peirce's pragmatic maxim, aims at eliminating as unsubstantiated issues all those philosophical (and non-philosophical) questions that do not refer to "actual or even simply possible expectations of ours"; 2) the pragmatism of "the will to believe," which temporarily or definitively refrains from pronouncing itself on the question of the truth or falsity of beliefs (with clear reference to the James-Schiller-Prezzolini trend of thought); 3) "a third variety [...] which recognizes the great role played by active and voluntary transactions in the progress of our knowledge, which draws different methodological consequences from it, relating to the sphere of definitions, hypotheses and experiments." This third form is clearly inspired by the idea of pragmatism as a philosophical ratification of the experimental scientific method. It recognizes an ethical quality also in the pragmatism of the "willingness to believe," since this form is implicitly close to the criterion of the voluntary construction of experimental hypotheses that contribute to modify - positively or negatively - our beliefs. However, Calderoni's penchant for positivistic trust in scientific knowledge pushes him towards an ethic based on clarity, confrontation with facts and, especially, on the conception of experience as an 
"uncomfortable and severe teacher." According to Calderoni, this concept essentially characterizes Peirce's pragmatism and his divergence from James.

The distinction between a "respectable" pragmatism and a non-Peircean "degenerate" pragmatism - the pragmatism of James and the Oxfordian Ferdinand Canning Scott Schiller - has produced an interpretative koiné which is deeply rooted in the Italian philosophical culture. One fact contributed to this phenomenon. Calderoni's controversy with James was connected with the heated discussions among the young intellectuals who created the Florentine magazine "Il Leonardo." These discussions testify the widening gap between two different ways of welcoming pragmatism, namely that of Vailati and Calderoni on the one hand, and that of Prezzolini and Papini on the other. These differences would soon have led to the conclusion of the story of "Il Leonardo." It is interesting to note that the two forms of reception of pragmatism were linked to conflicting political attitudes: the constant socialist orientation of the "logical pragmatists" and - after the conclusion of the Leonardo - the sympathies for fascism expressed by Papini and Prezzolini, who, moreover, later distanced themselves from it. In this regard, Vincent Colapietro noted the contrast between "the exuberant denial of human limits" by Prezzolini and "the humble recognition of them" by Calderoni, and pointed to "the denial of the existence of any limits to human will" as an element that predisposed Prezzolini and Papini towards fascism.

4 Supposing hypothetically that these expressions partly reflect the thoughts of the socalled "magic" pragmatists Papini and Prezzolini, it would certainly be easy to prove how little they are compatible with James's thinking. However, the contrast between the pragmatism of Peirce and James as a "degenerate" form of the peircean version is still quite lively on the international philosophical scene. In various contexts I have refuted this opposition, trying to show affinities rather than the alleged radical differences between Peirce's pragmatist trend and that of James, Mead, Dewey and their more recent epigones.

5 To this end, it is worth noting an important point of convergence between Peirce and James, namely their common intention to make room for the core criteria of scientific methodology: Experimentalism, fallibility and the principle of "sociality." The allegedly individualist James did not fail to stress these points in The Meaning of Truth, the text in which he tried to respond to the various misunderstandings of his own philosophy, a text that, perhaps not by chance, has been ignored for a long time especially in Europe. ${ }^{1}$

6 However, Calderoni identified a firm point of divergence between Peirce and James precisely in their respective attitudes of "respect" and "suspicion" towards the scientific method. Calderoni would probably have reviewed some of his views on James, had he been able to have a deeper understanding of his work. Let us consider the following passage of the conference "Pragmatism and Humanism," in which James regretted the real misunderstandings caused by the title he had chosen for his most famous work: "I once wrote an essay on our right to believe, which I unluckily called the Will to Believe. All the critics, neglecting the essay, pounced upon the title. Psychologically it was impossible, morally it was iniquitous. The 'will to deceive,' the 'will to make believe,' were wittily proposed as substitutes for it." 2

7 Leaving these reflections in the background, I would now like to try to look a little more closely at the reasons for appreciating the pragmatism of Peirce that Calderoni offers us and the applications he proposes. As I mentioned earlier, Calderoni shares the ethical quality of Peirce's pragmatism, for example his emphasis on the values of clarity, of 
confrontation with facts and, especially, of the conception of experience as "boaring but indispensable" (Calderoni 2007: 70). Starting from these criteria, which are both ethical and epistemological values, he introduces his most original arguments. First of all, the understanding of the meaning of terms and concepts by means of examples rather than definitions, in relation to their use and "grammatical" relationships - as Wittgenstein will later say - with other terms or concepts - in short, in relation to a given semantic context.

On this issue, introduced in the review of Giorgio Del Vecchio's book "The philosophical assumptions of the notion of law" (1905), ${ }^{3}$ Giovanni Tuzet wrote interesting and precise pages. ${ }^{4}$ Tuzet clearly highlighted the points of difficulty that emerge when one tries to explain the meaning of legal and moral concepts and their normative character through the application of Pierce's maximum pragmatic approach, which as we have seen Calderoni interprets in terms of predicting the probable consequences of an idea or belief. It is appropriate, however, to take up here a few passages of the text under discussion:

The need for a real "definition" is not always felt: it is sufficient, sometimes, to make a word usable, to indicate a number of examples chosen conveniently, by trusting in a vague similarity that we perceive, or we suppose to exist among the examples themselves, without however indicating in what this resemblance consists [...] The need of knowing the meaning of a word does not arise therefore as long as there is consensus in the use of it. In fact, it is felt strongly every time dissent arises between those who have to apply it [...] All sciences, all disciplines have their "difficult cases," which are unknown to the routiniers of the sciences and disciplines themselves: these need prompt the need to define what the routiniers find evident, obvious, intuitive; in them lies in the fact, the "practical" justification of every philosophy. Philosophy is born, therefore, from dissent and it presupposes dissent. ${ }^{5}$

In addition to the questions related to the understanding of meaning, we find in these passages a precise definition of the origin and task of philosophy, understood as a therapeutic activity that aims at identifying and dissolve the "mental cramps," the "enchantments" produced by the use of language itself, as Wittgenstein later said.

The comparison with Wittgenstein is particularly interesting if one considers Calderoni's reflections on the distinction between voluntary and involuntary acts, on which the theme of individual responsibility - both moral and juridical - is based. The ethics of clarity, inspired by Peirce's pragmatic maxim, is expressed in the proposal to address the question of the meaning of words or concepts through the production of examples and, sometimes, the display of objective references of words. This same strategy must also be adopted when we try to clarify issues relating to the concept of human will. It is necessary to start from the observation and description of the events of everyday life in order to understand what expressions such as "voluntary" and "involuntary" mean, as long as these expressions recur continuously and, above all, in a "spontaneous" way in our ordinary practices. The distinction between voluntary and involuntary acts belongs to our language as well as to our emotional attitudes. At the emotional level, it makes a big difference if we judge a certain event as the result of a voluntary act or of an involuntary cause - e.g. natural causes or human actions which cannot be attributed to the voluntariness of the subjects involved. There will be different emotional/affective reactions to the same event, depending on their explanation in terms of voluntary cause, or vice versa. 
11 On the other hand, according to Calderoni a key role is played by the clarity and obviousness through which the distinction between voluntary and involuntary presents itself, both in relation to acts already carried out and those still to be carried out. It is interesting to underline the theoretical question that emerges from these statements, namely the intention to seek a way to eliminate the contrast between science and ethical practice. On the one hand, this intention is in line with positivistic confidence in scientific knowledge - in fact, Calderoni stresses the need to bring ethical analysis back to the criteria of the scientific knowledge and method; on the other hand, we can observe here an anticipation of the typical tendency of the second twentieth century to go beyond a fixed point of logical positivism, namely the clear distinction between the scientific sphere and the practical sphere, and the certainty that these two domains are governed by completely heterogeneous criteria - respectively, a subjective-emotional and an objective-rational one.

More specifically, Calderoni claims that the characteristic of voluntary action consists in being "capable of being provoked or modified by the prediction of specific events, both outside of us and within us."6 A questionable clarification, since the range of possible predictions is always related to a number of potentially indefinable factors. However, Calderoni does not fail to pay attention to the distinction between "being able to predict" and "knowing how to predict." This distinction is clearly crucial for the attribution of moral or legal responsibility for an act. Calderoni expresses a strong disappointment with regard to the "Lombarans" who claim an equivalence between power and will, against which - writes Calderoni - the common sense rebels.

For the purposes of comparison with Wittgenstein and the theorists of the action that have followed his traces, Calderoni's distinction between the explanation of the material properties - e.g. colours - and the explanation of whether or not human actions are voluntary plays an interesting role. According to Calderoni, the explanation of material properties can be met ostensively, while the explanation of the voluntariness or involuntary nature of human actions requires an ad hoc experimental procedure, suitable to verify whether a certain act would have been repeated in any possible circumstance. Calderoni sets a difference between voluntariness and involuntary acts, which corresponds to the difference between elasticity and plasticity of physical bodies. In this way the possibility is ruled out that the voluntary act can consist only in the memory of past experiences, since it is rather characterized by a cognitive component whose specific nature consists in being a conditional prediction. This last aspect represents the constitutive trait of voluntariness and coincides with the meaning of human freedom. ${ }^{7}$

On this point, there is a divergence with Wittgenstein. With regard to the analysis of intentional verbs - e.g. deciding, intending, wanting, saying, etc. - Wittgenstein refuses the confusion caused by the continuous interference of physical language with all our discourse forms: "All our ways of speaking are borrowed from the normal physical language and are not to be used in epistemology or phenomenology without putting the subject to a wrong light." ${ }^{8}$ The grammar of will has its own specific status, which has very little to do with the knowledge of any past experience or with the verifiability or falsifiability of asserts in which terms such as "volunteer" or "involuntary" appear. Rather, it is necessary to refer to the plan of practical reason, and to the subjectively constituted normativity that characterizes its articulation and its possible developments. A similar argument can be found in Calderoni, if we move on to the ground of his observations about legal or moral responsibility, a domain that is obviously close to that 
of voluntariness/liberality. In this context, normativity is defined as a social product, by affirming the close link between the existence of rules of conduct and customs and the very concept of responsibility. Calderoni affirms in short that the meaning of the term responsibility alludes to certain "artificial" consequences - i.e. produced by society and its history - which certain acts imply. ${ }^{9}$

It is not clear how the definition of normativity as a "social product" can be linked to a conception of will which is still imbued with a "factual" human ontology. I would therefore like to focus on his clarification that "the norms of custom" imply "constant ways of reacting to the actions of others," 10 bearing in mind that Calderoni tends to combine a pragmatic approach to the conceptual network of notions of will, responsibility and normality with a brentanian approach to the problem of explaining human action.

16 As we know, scholars often singled out into Brentano's thought an "internalist/ mentalist" perspective that is not entirely consistent with Peirce's pragmatism. And yet Calderoni invites us to value Brentano's theory of "mental facts," according to which they must be distinguished in representations or ideas and beliefs and judgments, defining the latter as mental facts susceptible to truth or falsity, precisely because they imply predictions or expectations: ${ }^{11}$

What distinguishes voluntary action from involuntary action is precisely this: that voluntary action is what counts among its causes some judgments, some predictions in general, and in particular predictions relating to the act itself that is about to take place. Voluntary action is the kind of action that can be provoked or modified by the prediction of specific events, both outside of us and within us, and more particularly by the prediction of what would happen if the action were to be carried out (the consequences, that is, of the action itself). ${ }^{12}$

Following Brentano, Calderoni maintains that beliefs or judgments are the phenomena that cause the voluntary act. Here the distance from Wittgenstein is considerable. Within the phenomenological framework inspired by Brentano, intentionality is understood as the specific characteristic of the mind, and as what defines the relationship between states or mental processes and real facts, including those related to human action. On the other hand, according to Wittgenstein intentional verbs derive their meaning from certain relationships "internal" to the language itself, and not from the relationship between thought and reality to which Brentano sought, precisely, to link his notion of intentionality.

In Wittgenstein's Philosophical Investigations, this anti-Brentano position takes on a particularly interesting aspect in comparison with Calderoni. In a nutshell, Wittgenstein understands voluntary action in connection with a specific context and language games. The set of mutual expectations that are generated among speakers contributes to the creation of this context and these games. Intentional verbs express attitudes that depend on the agent and, at the same time, on the language game within which he acts. They depend on contexts "which we govern" and which, precisely for this reason, differ from linguistic games relating to physical or psychological facts, which instead happen regardless of our will, i.e. "whether we want it or not." ${ }^{13}$ Wittgenstein thus invites us to recognize the strength and permeability of the normative dimension of human life. As free persons, we are responsible for the standards that we ourselves build and which, precisely for this reason, we can also potentially change. While Calderoni tends to assimilate human freedom to the logical capacity to construct predictions, the wittgensteinian perspective attributes it instead, and in apparent paradox, to the 
normativity interweaving human actions. The freer are these action, the more they are normatively determined. ${ }^{14}$

Following Wittgenstein, Georg Henrik Von Wright elaborated a conception of free actions that can supplement Calderoni's observations on the relationship between freedom and determinism. As Pastore observes, Calderoni frames the relationship between freedom and determinism into a compatibilist vision that has an important predecessor in Hume: "Will and choice are determined by our history, our experience, our circumstances, the environmental and family influences that have formed us. Actions are determined by human will, which, in turn, is determined by factors external to the agent." (Pastore 2016: 379). In this same direction, Von Wright's studies converge in his neo-wittgensteinian theory of action, in particular in the notion of "action for reasons," a concept he defines as "twin" to the concept of free action..$^{15}$ If the very concept of cause itself brings with it the idea of the rigidity of the laws of nature, affirming the centrality of "reasons" means understanding the exercise of the ability to reason as the domain of the meanings and of the interpretations of terms or concepts that gradually intervene in the assessments of our and others' behaviours. This entails setting aside the idea according to which this capacity implies a causal relationship with respect to action, thus providing an exact, unambiguous logical explanation of the individual actions.

As we have seen, the term "cause" occupies a steady position in Calderoni's notes on human actions. On the other hand, it is likely that he would have subscribed to Von Wright's assertion that the concept of freedom is a logical presupposition for the comprehension/explanation of all these phenomena, namely that the concepts used to describe and explain human actions, such as motive, reason, choice, deliberation, etc., all relate to the idea of "freedom."

21 Perhaps a logical-semantic in-depth analysis could help to bring forward the ethical quality of Calderoni's pragmatism that I mentioned at the beginning of my speech. Moreover, it could also help to revisit the relationship between the normative level and the descriptive level, which his writings propose as a philosophical theme of primary importance. It seems therefore interesting to recall Wittgenstein's uses the expression "creative acts" to refer to what it is expressed by some intentional verbs and in particular the verb "will," just to underline that their normative status does not derive from past or possible experiences. In this way, I believe there is an interesting turning point with respect to the "logicist" rationalism that Calderoni has tried to defend contra James although Calderoni follows a theoretical approach that is far from being old-fashioned and, in any case, invites him to retrieve the most original traits precisely in order to revisit the concepts of rationality and human creativity. But then it is perhaps not entirely out of place to rethink also, without surrendering to irrationalist scepticism, to the prophetic expression of his friend and contender Giuliano the Sofist: "the rational animal will give way to the creative animal." ${ }^{17}$

In 1924, concluding his introductory pages to the two volumes in which he had collected the writings of Mario Calderoni, Giovanni Papini wrote:

Someone, sooner or later, will pick up the broken threads, the unfinished walls, and then, however absurd such a prophecy may seem today, Calderoni's thought will appear as one of the major contributions of Italian philosophy in the first decade of this century. ${ }^{18}$

There is no doubt that the originality of this philosopher, his ability to develop arguments and philosophical practices that anticipated important lines of twentieth-century 
philosophy, are now finally recognized. Therefore I believe that it is more than appropriate to accept the invitation of Papini to take up the "broken threads" of the short yet intense philosophical activity of Calderoni, and to attempt to develop further intertwining and articulations.

\section{BIBLIOGRAPHY}

CALDERONI Mario, (2007), Le varietà del pragmatismo, in Scritti sul pragmatismo, a cura di A. Di Giovanni, Bonanno Editore, Acireale-Roma, 69-78.

CALDERONI Mario, (2007), Variazioni sul pragmatismo, in Scritti sul pragmatismo, a cura di A. Di Giovanni, Bonanno Editore, Acireale-Roma, 79-97.

CALDERONI Mario, (1924), Scritti di Mario Calderoni, Firenze, La Voce editrice, vol. I-II.

EGIDI Rosaria, (2008), Intendere e volere nelle "Ricerche filosofiche," in Id. (a cura di), Wittgenstein. Rileggere le 'Ricerche', "Paradigmi,” XXVI, n.s. 2, 83-98.

JAMEs William, (1907), "Pragmatism and Humanism," Lecture 7 in Pragmatism: A new name for some old ways of thinking, New York, Longman Green and Co, 100.

JAMEs William, (1975), The Meaning of Truth. A Sequel to Pragmatism, Cambridge, MA, Harvard University Press. The first italian traduction Il significato della verità. Una prosecuzione di Pragmatismo, ed. F. Bordogna, Torino, Aragno, 2010.

PAPINI Giovanni, (1924), "Prefazione," G. Papini (a cura di), Scritti di Mario Calderoni, Firenze, La Voce editrice, vol. I.

PASTORE Baldassarre, (2016), "Pragmatismo e diritto penale. Le riflessioni di Mario Calderoni su "libero arbitrio e impossibilità'," Quaderni fiorentini per la storia del pensiero giuridico moderno, 45.

PREZZOLINI Giuseppe, (1907), L'arte di persuadere, Firenze, F. Lumachi.

TUZET Giovanni, (2007), "Ha senso fare previsioni normative? Pragmatismo ed etica in Calderoni," in Giovanni Maddalena \& Giovanni Tuzet (a cura di), I pragmatisti italiani, Milano, AlboVersorio ("Pragmata").

TUZET Giovanni, (2012), La pratica dei valori. Nodi tra conoscenza e azione, Macerata, Quodlibet. WITTGENSTEIN Ludwig, (1953), Philosophical Investigations, G.E.M. Anscombe \& R. Rhees (eds), Oxford, Blackwell.

VON WRIGHT Georg Henrik, (1980), "Freedom and Determination," in Acta Philosophica Fennica, XXXI.

VON WRIGHT Georg Henrik, (1981), "Explanation and Understanding of Action," Revue Internationale de Philosophie, 35. 


\section{NOTES}

1. James 1975 (the first italian traduction 2010).

2. James (1907: 100).

3. Calderoni (1924, vol. I: 275-83).

4. Tuzet (2007: 53-74; 2012: 125-40).

5. Calderoni (1924, vol. I: 276).

6. Calderoni (1905: 102).

7. Calderoni (1924, vol. I: 41-3, e 68).

8. See Wittgenstein (1953: §57c).

9. Calderoni (1924, vol. II: 59-60).

10. Calderoni (1924, vol. II: 60).

11. Calderoni (1905: 101).

12. Calderoni (1905: 102); see also Calderoni, I postulati della scienza positiva ed il diritto penale (1924, vol. I: 99).

13. Wittgenstein (1953: §116).

14. See Egidi (2008: 100).

15. Von Wright (1981: 133).

16. Von Wright (1980: 67).

17. Prezzolini (1907: 102).

18. Papini (1924, vol. I: $x)$.

\section{ABSTRACTS}

The paper firstly reconstructs Mario Calderoni's criticism of the Jamesian version of pragmatism, which corresponds to his philosophical choice in favor of the ethical value assigned by Peirce to the scientific-experimental method. In this light, I propose a reading of some Calderoni's arguments concerning the link between the construction of beliefs, practical norms and moral or legal responsibility, trying to reassess his criticisms of James and then his conception of philosophy as a practical and therapeutic activity. The latter will be discussed considering Wittgenstein's analysis of intentional verbs and Calderoni's approach to the issues of freedom, of the definition of voluntary acts as well as of individual responsibility, both moral and legal. In particular, I will focus on the paradigm shift suggested by Wittgenstein with regard to the problem of human will, which seems useful for enhancing Calderoni's pragmatist insights.

\section{AUTHOR}

\section{ROSA M. CALCATERRA}

Università Roma Tre

Rosamaria.calcaterra[at]uniroma3.it 